\title{
Literacy Questions Based on Hots Using Context Covid-19
}

\author{
Linda Puspitasari1 ${ }^{*}$, Zahra Alwi ${ }^{2}$, Suhardi ${ }^{3}$, Zulkardi ${ }^{4}$ \\ 1,2,3,4 Universitas Sriwijaya, Palembang, Indonesia
}

\section{A R T I C L E IN F O}

Article history:

Received April 19, 2021

Revised April 20, 2021

Accepted September 24, 2021

Available online November 25, 2021

\section{Kata Kunci :}

Literacy, HOTS-based literacy questions; PISA

Keywords:

Literasi, Soal Literasi Berbasis HOTS, PISA

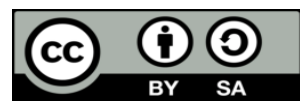

This is an open access article under the CC BY-SA license.

Copyright (C) 2021 by Author. Published by Universitas Pendidikan Ganesha

\begin{abstract}
A B S T R A K
Munculnya permasalahan dalam soal literasi berbasis HOTS ini disebabkan karena kurangnya pemahaman guru dalam mengembangkan soal. Guru harus mempersiapkan siswa yang memiliki kemampuan dengan mengintegrasikan keterampilan abad 21 ke dalam proses pembelajarannya. Rata-rata skor PISA 2018 mengalami penurunan di tiga bidang kompetensi dengan penurunan terbesar dalam membaca. Hal ini akan berdampak pada kemampuan siswa yang rendah. Tujuan penelitian ini yaitu mengembangkan soal berbasis Higher Order Thinking Skills (HOTS). Jenis penelitian ini yaitu pengembangan. Metode yang digunakan dalam penelitian ini adalah penelitian dan pengembangan. Pengumpulan data yang digunakan adalah teknik studi literatur, angket, focus group discussion, dan one-to-one test. Data yang diperoleh dari hasil studi pustaka berupa review kurikulum dan literatur terkait PISA, menalar, soal HOTS, dan media pembelajaran digital berupa website/youtube. Data yang diperoleh dari wawancara, kuesioner, dan diskusi kelompok terfokus dianalisis secara deskriptif kualitatif, dan kuantitatif. Hasil penelitian yaitu dihasilkan prototipe 1 soal literasi berbasis HOTS yang mengikuti standar PISA. Siswa berkemampuan tinggi menjawab salah soal nomor 6, mendapat nilai 9. Siswa berkemampuan sedang menjawab salah soal nomor 6 dan 10, mendapat nilai 8. Siswa berkemampuan rendah menjawab salah soal nomor 4 dan 10mendapat nilai 8. Rata-rata nilai yang diperoleh 3 siswa (dari kelompok tinggi, sedang, dan rendah) adalah 83,3. Sehingga termasuk dalam kategori sangat baik berdasarkan kriteria penilaian yang diberikan pada bagian metode. Dapat disimpulkan bahwa soal literasi berbasis HOTS dapat meningkatkan kemampuan siswa.
\end{abstract}

\section{A B S T R A C T}

The emergence of problems in HOTS-based literacy is due to the teacher's lack of understanding in developing questions. Teachers must prepare students who can integrate 21 st-century skills into their learning process. The average PISA 2018 score experienced a decline in three competency areas with the most significant reduction in reading. It will have an impact on the low ability of students. This research aims to develop questions based on Higher Order Thinking Skills (HOTS). This type of research is development. The method used in this research is research and development. The data collection used is literature study techniques, questionnaires, focus group discussions, and one-to-one tests. The data obtained from the study are in the form of curriculum reviews and literature related to PISA, reasoning, HOTS questions, and digital learning media in the format of websites/youtube. The data obtained from interviews, questionnaires, and group discussions focused on qualitative and quantitative descriptive. The result of the research is that the prototype produced 1 HOTS-based literacy question that follows the PISA standard. High-ability students answered question number 6, got 9. Students with moderate ability responded to questions number 6 and 10 , got a score of 8 . Low-ability students who responded to questions number 4 and 10 got a score of 8 . The average score obtained by three students (from the high group, medium, and low) was 83.3. They were included in the very good category based on the criteria given in the method section. It can be said that HOTS-based literacy can improve students' abilities.

\section{INTRODUCTION}

The emergence of problems in hots-based literacy questions is due to the Regulation of the Minister of Education and Culture of the Republic of Indonesia. The implementation of the UN in 2021 will be changed to a Minimum Competency Assessment and Character Survey, one of which consists of the ability to reason using language (literacy) (Anggriani et al., 2020; Johnston, 2020; Rahmadhani et al., 2019). Students who are in the middle of the school level will participate in the assessment (for example, grade 4 SD, 8 SMP, 11 SMA or equivalent). The results of the assessment will not be used as the basis for selecting students to continue to the next level of education (Irawana \& Taufina, 2020; Subagia \& Wiratma, 2016). Teachers will start to enter a new era where their primary duties and functions are really to be able to prepare students to live up to their time by integrating 21st-century skills into their learning process (Nithyanantham et al., 2019; Sudirman, 2019). The form of questions will be adjusted to the standard of the 
Program for International Student Assessment (PISA). As it is known, Indonesia has participated in the PISA survey for seven rounds from 2000-2018. Several things need to be improved, one of which is the competency in reading/literacy (Istiandaru et al., 2015; Susongko \& Afrizal, 2018). The 2018 PISA average score decreased in three competency areas with the largest decrease in reading. The reading ability of Indonesian students with a score of 371 in position 72 (S. Nugrahanto \& Zuchdi, 2019; Septya Nugrahanto \& Zuchdi, 2019). The reading ability of the OECD score in PISA is not only about literacy skill (writing) but also in the ability to understand reading in various difficulty levels. The average reading score across OECD countries is 487 . The basis for assessing reading literacy achievement is the student's ability to understand, use, and reflect on written texts to achieve goals (Koyuncu \& Firat, 2020; Supriyadi et al., 2020).

PISA questions are always oriented towards problem-solving, not just memorizing. PISA questions use high reasoning. According to PISA, literacy will have an impact on economic capability in the future (Koyuncu \& Firat, 2020; Susongko \& Afrizal, 2018). Indonesia is classified as a country that has not been able to create children's ability to think critically and analytically as adults should do in facing the highly heavy demands of the era (Amaliyah \& Nasrudin, 2019; Crismono, 2017). Low reading interest is a serious problem for the Indonesian nation because through books we can find out various information and train the brain to think critically so that it can produce an intelligent society (Antara \& Aditya, 2019; Fitri \& Afnita, 2020; Sukma \& Haryadi, 2016). Considering how low reading interest in Indonesia is, it is our responsibility to change it. Reading habits emerge from the closest education environment, namely the family environment. Parents should allocate specific time to read consistently so that children get used to reading (Siregar \& Rahmah, 2016).

Besides, use gadget technology more wisely, so it can have a positive impact on the increase of literacy (Hashim, 2018; Mutohhari et al., 2021). For the government, the distribution of regional libraries should be improved, so remote areas can participate in increasing Indonesian literacy for the sake of national intelligence. Moreover, the role of educators was not spared, teachers also take part, so that early age reading habits could be created (Johnston, 2020; Siti Nurwaqidah \& Suciati, 2020). Producing a generation in the complex 21st-century era is not easy. There are many skills that this generation needs to master (Lavi et al., 2021; Luciana, 2020). In general, it is divided into three categories, namely the quality of character, competence, and literacy. To achieve all these skills, it is necessary to stimulate students' thinking. One of them is by triggering children to solve problems or questions that require thinking skills, such as questions that require higher-order thinking (Anwar et al., 2020; Tanudjaya \& Doorman, 2020; Zulfiani et al., 2020).

HOTS questions can be interpreted as questions that can stimulate thinking skills that are not just remembering, restating, or reciting, but also being able to think critically and creatively (Mustika \& Susanti, 2020; Muzayyanah et al., 2020). Problems with difficult terms and unknown or rarely used do not necessarily include HOTS questions if they do not involve reasoning (Destiniar et al., 2020; Widana, 2020). The characteristics of HOTS questions are measuring higher-order thinking skills, minimizing aspects of remembering and understanding, based on contextual problems, interesting stimuli, familiarity, and novelty (Acesta, 2020; Prastikawati et al., 2021). The stages of compiling HOTS questions are by analyzing Basic Competence (KD) that can be created into HOTS questions, arrange question clues, choose an attractive and contextual stimulus, write the question items on the question card according to the question clues. The questions are written following the writing requirement of the question items and create scoring guidelines or answer keys related to this. The authors developed HOTS-based literacy reasoning questions in the form of test questions by using the Program for International Student Assessment (PISA) as their reference (Anisah \& Lastuti, 2018; Kurniati et al., 2016; Saraswati \& Agustika, 2020). It needs to be done since the PISA score of students from Indonesia is always low. In solving PISA-type questions, it requires students to think at a higher level, and students need to be accustomed to solving questions that require higher-order thinking (Acesta, 2020; Ndiung \& Jediut, 2020). It was also explained from the same source that by getting students used to working on PISA type questions, it would improve students' higher-order thinking skills.

The step of compiling HOTS-based questions has the same steps as arranging the usual questions (Anisah \& Lastuti, 2018; Kurniati et al., 2016; Saraswati \& Agustika, 2020). The difference is in the use of stimuli in the form of presenting problems in everyday life. HOTS-based questions require students to think about how to apply the facts or concepts that have been mastered. Meanwhile, the questions that are not based on HOTS are more inclined to simple types of questions that only measure students' memory ability or understanding of a concept and do not present contextual problems related to everyday life (Destiniar et al., 2020; Ndiung \& Jediut, 2020). HOTS is a deep thought process about information processing in completing and solving complex problems. The dimensions of knowledge in HOTS questions include the thinking process at the C4 (analysis), C5 (evaluation), and C6 (creating) levels (Astra et al., 2020; Muzayyanah et al., 2020). The characteristics of HOTS-based literacy questions are measuring high-order 
thinking skills, using problems in everyday life, and using various types of questions (Destiniar et al., 2020; Tyas et al., 2019). The strategy of compiling HOTS-based literacy questions consists of several steps, namely conducting an analysis of the basic competencies to be made into HOTS questions, compiling question grids, using interesting problems in everyday life, writing the questions, and making assessment guidelines and answer keys. Based on the background above, it is necessary to do research and development. The aim was to produce a set of literacy questions based on HOTS as a substitute for UN questions following the PISA standards. This research was expected to provide theoretical and practical benefits for teachers and students. For other researchers, this set of questions can be used for the development of further questions.

\section{METHODS}

The method used in this study is research and development. The development of teaching materials conducted in this study was a HOTS-based literacy. The research procedure is as follows. First, Preliminary stage. Identifying needs based on the analysis of existing UN questions to produce new HOTSbased questions. Review the curriculum and literature related to PISA, reasoning, HOTS questions, and digital learning media in the form of websites/ YouTube. Designing questions, preparing research instruments in the form of clues, question cards, answer keys, and scoring guidelines. Then conduct an assessment of the resulting test set. Second, Formative Evaluation Stage; self-evaluation, expert review/focus group discussion, one-to-one, small group, and field test. (It has not been conducted, yet, still waiting for the revised results from the one to one test).

The subjects of this research were students of seventh-graders of SMP Negeri 1 SemendeDaratLaut. Identification of the need for teaching materials to research subjects was conducted in one group class. Researchers distributed questionnaires and conducted interviews in the class. Two teachers were the participants in this study. The two teachers were also given a questionnaire that was used as input in developing HOTS-based literacy questions. Besides, the researcher also conducted interviews with the teacher to strengthen the information obtained from the questionnaire. The data collection used were literature study techniques, questionnaires, focus group discussions, and a one-to-one test. Data obtained from the results of literature studies are in the form of reviewing curriculum and literature related to PISA, reasoning, HOTS questions, and digital learning media in the form of websites/ YouTube. Data obtained from interviews, questionnaires, and focus group discussions were analyzed descriptively qualitatively, and quantitatively. Analysis of the one-to-one test results data was categorized: very good (grades 64-84), good (43-63), fair (22-42), and in poor categories (0-21). As for the success criteria in this study is the production of HOTS-based literacy questions following the PISA standard for junior high school level equipped with clues and answer keys.

\section{RESULT AND DISCUSSION}

\section{Results}

Based on the results of the literature study and interviews with respondents who were the subjects in this study, it was found that the teachers and students did not know the form of questions that would be used to replace the National Examination (UN). It was concluded that it was necessary to examine the existing UN questions to produce new HOTS-based questions. The development of literacy questions is indeed needed to help teachers and students face the implementation of the minimum competency assessment in 2021. Furthermore, an investigation on the curriculum and literature related to PISA was conducted, reasoning on HOTS questions to design questions, preparing research instruments in the form of clues, question cards, answer keys, and scoring guidelines. In this case, a prototype 1 of a HOTS-based literacy problem was produced that was following PISA standards.

These questions were assessed through several stages: self-evaluation, expert review with focus group discussion, and one-to-one test. Self-evaluations were conducted by researchers by looking at the deficiencies in the questions, both in terms of content, structure, and typing. After revising the design, then the design was distributed to expert reviews for a focus group discussion. Before the focus group discussion, the questions were validated by experts. Several improvements have been made based on the validator's suggestions, namely as follows. In question number 1 , there was a poster for a healthy life community movement following the WHO recommendation. The question asked the conclusions obtained from the health poster information. According to the validator of question number 1, the subject matter was not in line with the stimulus so that it made the stimulus (poster) did not function. Therefore, it was better to just replace the text. For question number 2, the news text came from "batampos.co.id". According to the validator, stimulus questions in the form of text in the box did not work at all, so it was better to remove it. If the use of text was necessarily needed, no need to use all the text, just take the necessary parts. For 
question number 3, according to the validator, the phrase "chatbotWhatsUp" did not need to be used. This phrase did not need to be quoted because it has appeared in the previous sentence.

After the revision based on the validator's suggestion, prototype two was obtained. Then a focus group discussion was conducted using a zoom. The experts who participated in this activity were three junior high school teachers, a research team, and two guest lecturers. The activities during the zoom meeting were discussing one by one the questions that had been previously distributed to the experts, analyzed the material and the context of the questions, whether they met HOTS, and following PISA standards. Then the experts checked the mechanics of the writing. According to experts, these questions can be understood and have used proper and correct language. A one-to-one test was conducted through a zoom meeting after obtaining questions from focus group discussion. The meeting was attended by two teachers, a research team, and three students. Students who were the subject are A (from the high group), FPO (from the moderate group), and MRA (from the low group). The results showed that high-ability students answered incorrectly to question number 6, got a score of 9; moderate capability students answered incorrectly to question number 6 and 10, got a score of 8; and low-ability students answered incorrectly to question number 4 and 10 , got a score of 8 . The average score obtained by the 3 students (from the high, moderate, and low groups) was 83.3. It was included as a very good category based on the assessment criteria provided in the method section. Students were asked to read and examine the items being tested, to provide comments, the obstacles faced, and suggestions on the questions being tested. The following are the comments given by the 3 students in Table 1 .

Tabel 1. Comments were given by students on the questions being tested

\begin{tabular}{|c|c|}
\hline & Question \\
\hline 1 & $\begin{array}{l}\text { After observing the pictures and text on the side, what } \\
\text { conclusions can you make about the use of masks based } \\
\text { on the health protocol? }\end{array}$ \\
\hline 2 & After reading the text, the character of Isdianto is.. \\
\hline 3 & $\begin{array}{l}\text { The National Disaster Management Authority (BNPB) } \\
\text { and the Ministry of Health will be the parties to "feed" } \\
\text { the chatbot system with factual information related to } \\
\text { Covid-19. In addition to the chatbot, the Ministry of } \\
\text { Communication and Informatics has also developed a } \\
\text { coronavirus emergency service center on } 117 \text {. The } \\
\text { meaning of ' feed' is ... }\end{array}$ \\
\hline 4 & $\begin{array}{l}\text { In your opinion, the reason people do not follow } \\
\text { government policies is ... }\end{array}$ \\
\hline
\end{tabular}

5 Those who agree that Covid-19 can be transmitted from person to person are ...

$6 \quad$ Maintaining personal hygiene to prevent the infection of the Covid-19 virus as recommended by the World Health Organization (WHO) is ...

$7 \quad$ Everyone maintains stamina, has a healthy lifestyle, do cough etiquette properly, and drinks lots of water are ways that can be done to maintain body endurance. The reason this to be done is to ...

8 When sneezing, or coughing in public, cover your mouth with a tissue or handkerchief. This is done because ...

$\begin{aligned} & \text { Comments from } \\ & \text { Moderate, and Low } \\ & \text { students }\end{aligned}$
ability

Question can be understood $(\mathrm{H})$

Question can be understood (M) Question can be understood (L) Question can be understood implicitly $(\mathrm{H})$

Question can be understood (M) Question can be understood (L) Question can be understood $(\mathrm{H})$ Question can be understood (M) Question can be understood (L)

Question can be understood $(\mathrm{H})$ Question can be understood (M) Question can be understood, the multiple-choice option is confusing because there is similar verb (L) Question can be understood $(\mathrm{H})$ Question can be understood (M) Question can be understood (L) Question can be understood $(\mathrm{H})$ Question can be understood (M) Question can be understood, the multiple-choice option is confusing because there is similar verb (L) Question can be understood $(\mathrm{H})$ Question can be understood (M) Question can be understood (L)

Question can be understood $(\mathrm{H})$ Question can be understood (M) Question can be understood (L) 


\begin{tabular}{lll}
\hline Question & $\begin{array}{l}\text { Comments from } \\
\text { Moderate, and Low ability } \\
\text { students }\end{array}$ \\
\hline $9 \quad \begin{array}{l}\text { The transmission can occur through close contact such } \\
\text { as working in a room or in a public facility that has been } \\
\text { infected to the virus from a patient. Things that we } \\
\text { should do to avoid the coronavirus are ... }\end{array}$ & $\begin{array}{l}\text { Question can be understood (H) } \\
\text { Question can be understood (L) }\end{array}$ \\
$\begin{array}{l}\text { Alcohol-based hand sanitizer is not a proper cleaning } \\
\text { agent as the source of eradicating dirt. Write down }\end{array}$ & $\begin{array}{l}\text { Questions can be understood, } \\
\text { information from news and seniors } \\
\text { your reasons! }\end{array}$ \\
& $\begin{array}{l}\text { Can be understood (M) } \\
\text { Questions can be understood, } \\
\text { information from people (L) }\end{array}$ \\
\hline
\end{tabular}

Based on the results of expert and one-to-one validation, the researcher revised prototype two to prototype three. The following were the context, text, and example items of the development results after self-evaluation, expert review, focus group discussion, and one-to-one test.

Table 2. Examples of the rubric of HOTS-based literacy questions

\begin{tabular}{|c|c|c|c|c|}
\hline No & Content & Context & Level & Answer Key \\
\hline 1 & Poster & Health & 4 & \\
\hline & \multicolumn{4}{|c|}{$\begin{array}{l}\text { Question: } \\
\text { After observing the pictures and text on the side, what conclusions can you make about the use } \\
\text { of masks based on the health protocol? } \\
\text { Options: } \\
\text { a. When leaving the house, use a mask, and wash your hands frequently. } \\
\text { b. How to prevent leaving the house during the Covid-19 period is to use a mask. } \\
\text { c. If it is a must to do activities outside the house, use a cloth mask. } \\
\text { d. Always wear a mask when needed. } \\
\text { Problem Solving: } \\
\text { Conclusion after observing the pictures and text on the poster, how to prevent is ... } \\
\text { c. If it is a must to do activities outside the house, use a cloth mask. }\end{array}$} \\
\hline & \multicolumn{4}{|c|}{ Answer Key: c } \\
\hline 2 & News text & Health & 4 & $\begin{array}{l}\text { a. A leader who is responsible for duties, } \\
\text { cares for subordinates and is religious }\end{array}$ \\
\hline & \multirow{2}{*}{\multicolumn{4}{|c|}{$\begin{array}{l}\text { Question: } \\
\text { After reading the quoted text above, please conclude the character figure of Isdianto ... } \\
\text { a. A leader who is responsible for duties, caring to subordinates, and religious. } \\
\text { b. A leader who is ignorant, irresponsible, and does not pay attention to the restlessness of his } \\
\text { subordinates. } \\
\text { c. A leader who is responsible for his duties, less concerned about his subordinates, and religious. } \\
\text { d. A leader who is busy with his work, less socializing with subordinates, and religious } \\
\text { Problem Solving: } \\
\text { Based on Batam news "text pos.co.id", the character figure of Isdianto is a leader who is } \\
\text { responsible for duties, caring to subordinates, and religious. } \\
\text { Answer Key: a }\end{array}$}} \\
\hline & & & & \\
\hline
\end{tabular}

The two examples of developed questions are examples of HOTS-based literacy questions. In level 3 cognitive, questions begun with images and text, the test taker needs to read the text and observe the images, understand them, then give the right answer based on the results of their understanding. This was done in line with the characteristics of HOTS-based questions, namely (1) being able to measure higherorder thinking skills, (2) using interesting problems or problems in daily life, and (3) using various types of 
questions. The step of compiling HOTS-based questions has the same steps as the common questions [10]. The difference is in the use of stimuli in the form of presenting daily life problems. HOTS-based questions require students to think about how the application of facts or concepts that have been mastered, contextual, and related to daily life.

\section{Discussion}

The steps conducted are also in line with the steps to compile HOTS questions, namely analyzing KD. The basic competence (KD) used as a guide to create HOTS questions, compiling question clues, choosing interesting and contextual stimuli, writing questions on question cards according to the question clues (Aspini, 2020; Destiniar et al., 2020). The question items were written following the writing requirement of the question items and create scoring guidelines or answer keys related to this. The authors developed HOTS-based literacy reasoning questions in line with these procedures and in line with the Program for International Student standards Assessment (PISA) (Fanani, 2018; Kristanto \& Setiawan, 2020; Widana, 2020). This needs to be done considering the PISA score of students from Indonesia is always low. It was also explained from the same source that by getting students used to working on PISA type questions it would improve students' higher-order thinking skills. In the problem, students need reasoning to be able to give reasons that the large number of Covid-19 victims will be associated with the distribution of masks in this case by the TNI and Polri. Student reasoning about the distribution of masks is associated with the large number of Covid-19 victims. in the student's answer, the distribution of masks was carried out because the number of Covid-19 victims continued to grow. The distribution of masks was in anticipation so that the number of victims would not continue to increase. The reasoning that the students expressed that there were more Covid-19 victims was one of the anticipations by distributing masks. In the student's answer, the distribution of masks was carried out by the TNI and Polri to help residents in anticipation of the many Covid-19 victims. Every problem in the context of Covid-19 students use their reasoning in order to come up with solutions to higher-order thinking problems. HOTS-based questions are effective in improving students' critical thinking skills (Acesta, 2020; Prastikawati et al., 2021; Saraswati \& Agustika, 2020).

Students' answers during the field test were able to understand literacy questions based on HOTS type PISA. Students can describe the procedures for Covid-19 in the funeral of Covid-19 patients that have been determined by WHO in Indonesia by applying health protocols and using hazmat for medical personnel. Unit 1 in the questions is the context of Covid-19 and the students' answers are correct according to critical thinking reasoning for PISA-type HOTS-based literacy questions. The way students answered also was supported in transcript. This means that HOTS-based questions can improve students' abilities (Astra et al., 2020; Narayanan \& Adithan, 2015; Tyas et al., 2019). The findings of previous studies also stated that HOTS can significantly improve students' abilities (Sidiq et al., 2021; Widana, 2020). Other research findings also state that HOTS can help students in learning (Afriyanti et al., 2021; Harta et al., 2020; Sagala \& Andriani, 2019). Based on the transcript, students read the text then use reasoning to be able to interpret the fixed procedure correctly. Then the students connected with the health protocol according to WHO recommendations so that Covid-19 could be reduced.

\section{CONCLUSION}

Based on the research and development that has been done, it can be concluded that the resulting literacy questions are different from the UN questions. HOTS-based literacy questions contained items that measured higher-order thinking competencies, in line with educational goals that want to develop higherorder thinking skills and other competencies that are more relevant to the 21st Century, as reflected in the 2013 Curriculum. The resulting questions have been through some processes such as self-evaluation, expert review, and focus group discussion.

\section{REFERENCES}

Acesta, A. (2020). Analisis Kemampuan Higher Order Thingking Skills (HOTS) Siswa Materi IPA Di Sekolah Dasar. Quagga: Jurnal Pendidikan Dan Biologi, 12(2), 170. https://doi.org/10.25134/quagga.v12i2.2831.

Afriyanti, M., Suyatna, A., \& Viyanti. (2021). Design of e-modules to stimulate HOTS on static fluid materials with the STEM approach. Journal of Physics: Conference Series, 1788(1). https://doi.org/10.1088/1742-6596/1788/1/012032.

Amaliyah, M., \& Nasrudin, H. (2019). Melatihkan Keterampilan Berpikir Kritis Peserta Didik Melalui Strategi Predict Observe Explain (POE) Pada Materi Kesetimbangan Kimia Kelas XI SMAN 11 Surabaya. 
Unesa Journal of Chemical Education, 8(3), 2252-9454. https://doi.org/10.1017/CB09781107415324.004.

Anggriani, A., Sarwi, S., \& Masturi, M. (2020). The Effectiveness of Guided Discovery in Distance Learning to Improve Scientific Literacy Competencies of Primary School Students. Journal of Primary Education, 9(5), 454-462. https://doi.org/10.15294/jpe.v9i4.42600.

Anisah, \& Lastuti, S. (2018). Pengembangan Bahan Ajar berbasis HOTS untuk Meningkatkan Kemampuan Pemecahan Masalah Matematis Mahasiswa. Kreano: Jurnal Matematika Kreatif-Inovatif, 9(2), 191197. https://doi.org/10.15294/kreano.v9i2.16341.

Antara, \& Aditya, P. (2019). Pengaruh Model Pembelajaran Kontekstual Terhadap Kemampuan Membaca Permulaan Anak. Mimbar Ilmu, 24. https://doi.org/10.23887/mi.v24i2.21263.

Anwar, Y., Selamet, A., Huzaifah, S., \& Madang, K. (2020). Training in developing higher-order thinking based online test instrument for biology teachers in Sekayu City. Journal of Community Service and Empowerment, 1(3), 150-155. https://doi.org/10.22219/jcse.v1i3.12241.

Aspini. (2020). Implementasi Pembelajaran PBL Berbantuan Media Kartu Soal Untuk Meningkatkan Kemampuan HOTS Pada Siswa Kelas VI SD. Jurnal Edutech Undiksha, 8(1), 72-79. https://doi.org/10.23887/jeu.v8i1.27087.

Astra, I. M., Raihanati, R., \& Mujayanah, N. (2020). Development of Electronic Module Using Creative Problem-Solving Model Equipped with Hots Problems on The Kinetic Theory of Gases Material. Jurnal Penelitian \& Pengembangan Pendidikan Fisika, 6(2), 181-194. https://doi.org/10.21009/1.06205.

Crismono, P. C. (2017). Pengaruh Outdoor Learning Terhadap Kemampuan Berpikir Kritis Matematis Siswa The Influence Of Outdoor Learning On The Mathematical Critical Thinking Skills Of Students. Junal Pendidikan Matematika Dan Sains, 4(2), 106-113. https://doi.org/10.21831/jpms.v5i2.15482.

Destiniar, Mulbasari, A. S., Fuadiah, N. F., Octaria, D., Ningsih, Y. L., Retta, A. M. R., \& Isroqmi, A. (2020). Pelatihan Penyusunan Soal HOTS untuk Mengambangkan Kemampuan Pedagogik Guru. JAPDIPAMAS (Jurnal Pengabdian Kepada Masyarakat), 4(1), 163-170. https://doi.org/10.30734/jabdipamas.v4i1.585.

Fanani, M. Z. (2018). Strategi Pengembangan Soal Higher Order Thinking Skill (HOTS) dalam Kurikulum 2013. Edudeena, 2(1), 57-76. https://doi.org/10.30762/ed.v2i1.582.

Fitri, M., \& Afnita. (2020). Korelasi keterampilan membaca pemahaman dan keterampilan menulis teks eksposisi siswa kelas VII SMP Negeri 11 Padang. Jurnal Penelitian Bidang Pendidikan, 26(2), 77-81. https://doi.org/10.24114/jpbp.v26i2.17925.

Harta, J., Rasuh, N. T., \& Seriang, A. (2020). Using HOTS-Based Chemistry National Exam Questions to Map the Analytical Abilities of Senior High School Students. Journal of Science Learning, 3(3), 143-148. https://doi.org/10.17509/jsl.v3i3.22387.

Hashim, H. (2018). Application of Technology in the Digital Era Education. International Journal of Research in Counseling and Education, 1(2), 1. https://doi.org/10.24036/002za0002.

Irawana, T. J., \& Taufina, T. (2020). Penggunaan Metode Problem Solving untuk Meningkatkan Motivasi dan Hasil Penilaian Pendidikan Kewarganegaraan Peserta Didik di Sekolah Dasar. Jurnal Basicedu, 4(2), 434-442. https://doi.org/10.31004/basicedu.v4i2.367.

Istiandaru, A., Istihapsari, V., Wardono, W., \& Mulyono, M. (2015). Problem Based Learning (PBL) Dengan Pendekatan Realistik-Saintifik dan Asesmen Pisa Untuk Meningkatkan Kemampuan Literasi Matematika. Edumatica: Jurnal Pendidikan Matematika, 5(1). https://doi.org/10.22437/edumatica.v5i01.2670.

Johnston, N. (2020). The Shift towards Digital Literacy in Australian University Libraries: Developing a Digital Literacy Framework. Journal of the Australian Library and Information Association. https://doi.org/10.1080/24750158.2020.1712638.

Koyuncu, İ., \& Firat, T. (2020). Investigating reading literacy in PISA 2018 assessment. International Electronic Journal of Elementary Education, 13(2), 263-275. https://doi.org/10.26822/iejee.2021.189.

Kristanto, P. D., \& Setiawan, P. G. F. (2020). Pengembangan Soal HOTS (Higher Order Thinking Skills) Terkait Dengan Konteks Pedesaan. PRISMA: Prosiding Seminar Nasional Matematika, 3, 370-376.

Kurniati, D., Harimukti, R., \& Jamil, N. A. (2016). Kemampuan berpikir tingkat tinggi siswa SMP di Kabupaten Jember dalam menyelesaikan soal berstandar PISA. Jurnal Penelitian Dan Evaluasi Pendidikan, 20(2), 142-155. https://doi.org/10.21831/pep.v20i2.8058.

Lavi, R., Tal, M., \& Dori, Y. J. (2021). Perceptions of STEM alumni and students on developing 21st century skills through methods of teaching and learning. Studies in Educational Evaluation, 70, 1-11. https://doi.org/10.1016/j.stueduc.2021.101002. 
Luciana, N. L. R. (2020). Teachers' Readiness in Inserting the 21st Century Skills in the Lesson Plan in Teaching English. Jurnal Pendidikan Dan Pengajaran, 53(2), 168. https://doi.org/10.23887/jpp.v53i2.26406.

Mustika, S. W., \& Susanti. (2020). Pengembangan lembar kerja peserta didik (LKPD) berbasis Higher Order Thinking Skill (HOTS) praktikum akutansi lembaga. Jurnal Pendidikan Ekonomi, 13(2), 409-414. https://doi.org/10.17977/UM014v13i22020p125.

Mutohhari, F., Sofyan, H., \& Nurtanto, M. (2021). Technological Competencies: A Study on the Acceptance of Digital Technology on Vocational Teachers in Indonesia. Proceedings of the 1st International Conference on Law, Social Science, Economics, and Education, ICLSSEE 2021, 1-11. https://doi.org/10.4108/eai.6-3-2021.2305971.

Muzayyanah, A., Wijayanti, A., \& Ardiyanto, A. (2020). Pengembangan lembar kerja peserta didik (LKPD) tematik berbasis HOTS (Higher Order Thinking Skill) kelas IV Sekolah Dasar. Jurnal Pijar Mipa, 15(5), 452-457. https://doi.org/10.29303/jpm.v15i5.1712.

Narayanan, S., \& Adithan, M. (2015). Analysis Of Question Papers In Engineering Courses With Respect To Hots (Higher Order Thinking Skills). American Journal of Engineering Education (AJEE), 6(1), 1-10. https://doi.org/10.19030/ajee.v6i1.9247.

Ndiung, S., \& Jediut, M. (2020). Pengembangan instrumen tes hasil belajar matematika peserta didik sekolah dasar berorientasi pada berpikir tingkat tinggi. Premiere Educandum : Jurnal Pendidikan Dasar Dan Pembelajaran, 10(1), 94. https://doi.org/10.25273/pe.v10i1.6274.

Nithyanantham, V., Paulmony, R., \& Ramadan H., S. (2019). Self-Perspective of 21st Century Educators: A Challenge in The Globalised Educational World. International Journal of Educational Research Review, 4(3). https://doi.org/10.24331/ijere.573869.

Nugrahanto, S., \& Zuchdi, D. (2019). Indonesia PISA Result and Impact on the Reading Learning Program in Indonesia. International Conference on Interdisciplinary Language, Literature and Education, 373377. https://doi.org/10.2991/icille-18.2019.77.

Nugrahanto, Septya, \& Zuchdi, D. (2019). Indonesia PISA Result and Impact on The Reading Learning Program in Indonesia. International Conference on Interdisciplinary Language, Literature and Education (ICILLE 2018), 297(0), 373-377. https://doi.org/10.2991/icille-18.2019.77.

Prastikawati, E. F., Wiyaka, W., \& Budiman, T. C. S. (2021). Pelatihan Penyusunan Soal Bahasa Inggris Berbasis HOTS bagi Guru Bahasa Inggris SMP. Jurnal Pengabdian Masyarakat, 6(1). https://doi.org/10.30653/002.202161.761.

Rahmadhani, E., Gradini, E., \& Firmansyah. (2019). Literasi Matematika Siswa Melalui Metode Murder (Mood, Understand, Recall, Digest, Expand, Review). Jurnal Pendidikan Dan Pembelajaran Matematika, 3(2). https://doi.org/10.22373/jppm.v3i2.7350.

Sagala, P. N., \& Andriani, A. (2019). Development of Higher-Order Thinking Skills (HOTS) Questions of Probability Theory Subject Based on Bloom's Taxonomy. Journal of Physics: Conference Series, 1188(1). https://doi.org/10.1088/1742-6596/1188/1/012025.

Saraswati, P. M. S., \& Agustika, G. N. S. (2020). Kemampuan Berpikir Tingkat Tinggi Dalam Menyelesaikan Soal HOTS Mata Pelajaran Matematika. Jurnal Ilmiah Sekolah Dasar Undiksha, 4(2). https://doi.org/10.23887/jisd.v4i2.25336.

Sidiq, Y., Ishartono, N., Desstya, A., Prayitno, H. J., Anif, S., \& Hidayat, M. L. (2021). Improving Elementary School Students' Critical Thinking Skill in Science Through Hots-Based Science Questions: A QuasiExperimental Study. Jurnal Pendidikan IPA Indonesia, 10(3), 378-386. https://doi.org/10.15294/jpii.v10i3.30891.

Siregar, A., \& Rahmah, E. (2016). Model Pop Up Book Keluarga Untuk Mempercepat Kemampuan Membaca Anak Kelas Rendah Sekolah Dasar. Ilmu Informasi Perpustakaan Dan Kearsipan. https://doi.org/10.24036/6288-0934.

Siti Nurwaqidah, S., \& Suciati, M. R. (2020). Environmental literacy-based on adiwiyata predicate at junior high school in Ponorogo. JPBI (Jurnal Pendidikan Biologi Indonesia), 6(3). https://doi.org/10.22219/jpbi.v6i3.12468.

Subagia, I. W., \& Wiratma, I. G. L. (2016). Profil Penilaian Hasil Belajar Siswa Berdasarkan Kurikulum 2013. JPI (Jurnal Pendidikan Indonesia), 5(1), 39-54. https://doi.org/10.23887/jpi-undiksha.v5i1.8293.

Sudirman. (2019). The 21st-Century Teacher: Teacher' s Competence Within the Character Education Framework Towards A Cultural-Oriented Development and Promoting Tolerance. Internationl Education Studies, 12(8), 21-25. https://doi.org/10.5539/ies.v12n8p21.

Sukma, S., \& Haryadi, H. (2016). Keefektifan strategi REAP dan request dalam pembelajaran membaca pemahaman siswa kelas VIII SMP. Lingtera, 3(1). https://doi.org/10.21831/lt.v3i1.8476. 
Supriyadi, T., Julia, J., Aeni, A. N., \& Sumarna, E. (2020). Action research in hadith literacy: A reflection of hadith learning in the digital age. International Journal of Learning, Teaching and Educational Research, 19(5), 99-124. https://doi.org/10.26803/ijlter.19.5.6.

Susongko, P., \& Afrizal, T. (2018). The determinant factors analysis of Indonesian students' environmental awareness in pisa 2015. Jurnal Pendidikan IPA Indonesia. https://doi.org/10.15294/jpii.v7i4.10684.

Tanudjaya, C. P., \& Doorman, M. (2020). Examining higher order thinking in Indonesian lower secondary mathematics classrooms. Journal on Mathematics Education, 11(2), 277-300. https://doi.org/10.22342/jme.11.2.11000.277-300.

Tyas, M. A., Nurkamto, J., Marmanto, S., \& Laksani, H. (2019). Developing higher order thinking skills (HOTS)-Based questions: Indonesian EFL teachers' challenges. Proceeding of the 2nd International Conference on Future of Education, 2(1), 52-63. https://doi.org/10.17501/26307413.2019.2106.

Widana, I. W. (2020). Pengaruh Pemahaman Konsep Asemen HOTS terhadap Kemampuan Guru Matematika SMA/SMK Menyusun Soal HOTS. Jurnal Emasains: Jurnal Edukasi Matematika Dan Sains, 9(1), 6675. https://doi.org/10.5281/zenodo.3743923.

Zulfiani, Suwarna, I. P., \& Sumantri, M. F. (2020). Science adaptive assessment tool: Kolb’s learning style profile and student's higher order thinking skill level. Jurnal Pendidikan IPA Indonesia, 9(2), 194207. https://doi.org/10.15294/jpii.v9i2.23840. 